guidance; at present our advice must be based on the results of extended and refined short-term studies-blended with common sense.

Professor of Obstetrics and Gynaecology,

JAMES S SCOTT

Department of Obstetrics and Gynaecology

(Leeds Maternity Hospital),

Leeds LS2 9NG

1 Doll R, Peto R. The causes of cancer. Oxford: Oxford University Press, 1982 .

2 Beral V. Cancer of the cervix: a sexually transmitted infection ? Lancet $1974 ; \mathrm{i}: 1037-40$.

${ }^{3}$ Miller AB, Rawls WE. Epidemiology of gynecologic cancer: I. Cervix. In: Coppleson $\mathrm{M}$, ed. Gynaecologic oncology. Vol 1. Edinburgh: Churchill Livingstone, $1981: 9-18$.

${ }^{4}$ Hulka BS, Chambless LE, Kaufman DG, Fowler WC Jr, Greenberg BG. Protection against endometrial carcinoma by combination-product oral contraceptives. $\mathcal{F} A M A 1982 ; 247: 475-7$.

5 Weiss NS, Sayvetz TA. Incidence of endometrial cancer in relation to the use of oral contraceptives. N Engl F Med 1980;302:551-4.

6 Kaufman DW, Shapiro S, Slone D, et al. Decreased risk of endometrial cancer among oral-contraceptive users. N Engl F Med 1980;303:1045-7.

7 Cohen CJ, Deppe G. Endometrial carcinoma and oral contraceptive agents. Obstet Gynecol 1977;49:390-2.

${ }^{8}$ British Gynaecological Cancer Group. Oestrogen replacement and endometrial cancer. Lancet 1981 ; : 1359-60.

- Beral V, Fraser P, Chilvers C. Does pregnancy protect against ovarian cancer? Lancet 1978; i:1083-6, 7.

10 Casagrande JT, Louie EW, Pike MC, Roy S, Ross RK, Henderson BE. "Incessant ovulation" and ovarian cancer. Lancet 1979;ii:170-2, 3.

${ }^{11}$ Beral V. The epidemiology of ovarian cancer. In: Newman CE, Ford $\mathrm{CHJ}$, Jordan JA, eds. Ovarian cancer: proceedings of the international symposium on ovarian cancer, 24-25 September 1979, Birmingham. Oxford: Pergamon Press, 1980:29-38

12 WHO Scientific Group. Steroid contraception and the risk of neoplasia. WHO Tech Rep Ser 1978; No 619.

${ }^{13}$ Goldzieher JW. Oral contraceptive hazards-1981. Fertil Steril 1981 ;35 : 275-6.

14 Shearman RP. Oral contraceptives: where are the excess deaths ? Med $\mathcal{F}$ Aust 1981 ; : $698-700$.

15 Vessey MP. Oral contraceptives and cardiovascular disease : some questions and answers. $\mathrm{Br} \mathrm{Med} \mathcal{F} 1982 ; 284: 615-6$.

${ }^{16}$ Ryan KJ. Endometrial cancer, epidemiology, and medical practice. $\mathscr{f} A M A$ $1982 ; 247: 496$.

\section{Good and bad news for medical schools}

Renée Short's Social Services Committee has confirmed in its most recent report UGC Cuts and Medical Services ${ }^{1}$ what everybody except perhaps the Government and the Department of Health and Social Security already knew-that teaching, research, and service work in medical schools will be severely damaged by university cuts. ${ }^{2}{ }^{3}$ The committee has recommended that an extra $£ 5 \mathrm{~m}$ in $1982-3$ and a further $£ 5 \mathrm{~m}$ in 1983-4 should be made available to protect the teaching of clinical medicine. (A summary of the conclusions and recommendations of the report is published on $\mathrm{p}$ 1720.) Prompted at the press conference to launch the report into the stronger language that is her true métier, Mrs Short said that it was "scandalous" that the Government should let the medical schools be so damaged. Furthermore, when discussing the amounts needed to protect the medical schools we were "talking about peanuts." The strong support and clear recommendation of the committee will be welcomed by the medical schools.

The main Parliamentary function of the Social Services Committee is to keep a close eye on the elephantine DHSS, and this it has done. In both the report and at the press conference the DHSS was strongly criticised for not making clear to the rest of the Government and to the UGC what dire effects the cuts would have on medical education. It was also taken to task for not monitoring carefully the effects of the cuts. The Rt Hon David Ennals, a former Secretary of State for Health and Social Security, and a current member of the Social Services Committee, said that he found the lack of communication between the DHSS, the DES, and the UGC "really extraordinary." The implication was that if the DHSS had done its job and made the UGC aware of what the cuts would mean to medical education then the cuts would never have been made.

The committee estimates that if the Government does not take further action then about 300 clinical academic posts might be lost by 1983-4. Patient care, teaching, and research are all being seriously affected, and what most concerns the committee is that it is shortage specialties and poorer regions that are being most sererely damaged. In its report on medical education $^{4}$ the committee called specifically for the expansion of academic posts in such specialties as a means of encouraging their development. Yet in the present round of cuts it is these very specialties that are most vulnerable. The committee wants the DHSS, the UGC, and the universities to strive to ensure their protection-and so they should. Rightly, too, the committee is not enthusiastic about the NHS taking over lost university posts. No government money is saved if salaries are paid by the NHS rather than by the universities, and such a policy would inevitably mean a shift away from essential teaching and research.

While medical schools will be cheered by the support of the committee, they will, as described by Professor Payne last week (29 May, p 1636), continue to be depressed by the gap between the $4 \%$ salary increase for doctors teaching in medical schools and the average increase of $6 \%$ for NHS doctors $(29$ May, $\mathrm{p}$ 1656). Doctors who enter the medical schools already often suffer financially for the privilege, and if this small but important discrepancy is not righted medical schools will find it still harder to attract the most able and keep up standards. Again, we are discussing Mrs Short's "peanuts," and again the damage done is likely to be quite out of proportion to the money saved. Mrs Short's committee points out that the problems it describes "can be resolved relatively easily and cheaply." So they can, and we join the committee in urging the Government to do so.

${ }^{1}$ Social Services Committee. UGC cuts and medical services. London: HMSO, 1982.

Walton J. An act of madness? Br Med F 1981 ;282:1150-2.

${ }^{3}$ Smith R. The starving of the medical schools. Br Med f 1982;284:335-7.

Social Services Committee. Medical education with special reference to the number of doctors and the career structure in hospitals. London: HMSO, 1981.

\section{Creutzfeldt-Jakob disease}

Creutzfeldt-Jakob disease is one of the spongiform encephalopathies, a group which also includes kuru and scrapie. The disease is extremely rare: its incidence has been calculated as 0.09 per million population, though this figure may be an underestimate. Most cases occur sporadically, but occasional reports have appeared of affected families. The illness usually presents between the ages of 40 and 60 , the sexes being equally affected. Most patients show the clinically characteristic picture, but a few present atypically, often with a more chronic course. Some patients die within months of onset, while others survive for several years; the average duration of illness is about a year. 
The classic picture is one of subacute, rapidly progressive dementia, often accompanied by florid psychiatric symptoms including visual and auditory hallucinations, and invariably associated with myoclonus. Indeed, the combination of myoclonus with a rapidly evolving dementia strongly suggests the diagnosis of Creutzfeldt-Jakob disease. A startle reaction may often be elicited. The patient becomes apathetic and confused with a poor memory and is dysphasic. Next he develops dysarthria, bulbar or pseudobulbar palsy appears, and dysphagia is common. Some patients present with cortical blindness, while others develop it in the course of the disease. Ataxia may appear early as evidence of cerebellar damage. Most patients finally become mute, and progressive rigidity and spasticity make them bedbound. Repetitive jerking of the muscles is still evident late in the disease. The duration of survival depends largely on the quality of the nursing care.

Less frequently the disease may pursue a more chronic course without myoclonus but accompanied by muscle atrophy and fasciculations, thus resembling motor neurone disease. This form may be confused with amyotrophic lateral sclerosis, Parkinson's disease, or Alzheimer's disease.

Laboratory investigations are of little help in diagnosis. The blood and cerebrospinal fluid show no abnormalities, apart from occasional evidence of mild liver dysfunction. At first the electroencephalogram shows only non-specific changes but later there may be high-voltage, bilaterally synchronous, polyphasic discharges which become periodic at a rate of one or two a second. A computed tomography scan is of little help because the ventricular enlargement is seldom severe. The diagnosis should be readily apparent clinically, but it may be confirmed by cerebral biopsy. Although the macroscopic appearance of the brain is unremarkable, microscopical examination shows neuronal loss, intense gliosis, and a finemeshed vacuolation suggesting minute accumulations of fluid. This vacuolation-spongiform encephalopathy-has been shown by electron microscopy to be due to vacuoles within the cytoplasm of astrocytes and neurones. The degree of change depends on the stage of the disease.

Research into Creutzfeldt-Jakob disease took off with the first report of its transmission to a chimpanzee by a cerebral biopsy specimen from a patient with the disease. The agent has also been passaged into other laboratory animals, including guinea-pigs, hamsters, and mice. Accidental transmission of Creutzfeldt-Jakob disease from man to man has been reported. ${ }^{1}$ Two young epileptics developed the disease after they had been studied with depth electrodes used previously in a patient with Creutzfeldt-Jakob disease; in another case, a neurosurgeon was affected.

Some time ago precautions were advised in necropsy and operating rooms if Creutzfeldt-Jakob disease was suspected, but the advice was confusing and difficult to put into practice. ${ }^{23}$ The matter has now been fully discussed by Matthews ${ }^{4}$ and by the advisory group on the management of patients with Creutzfeldt-Jakob disease, which has recently made its recommendations to the Chief Government Medical Officers. ${ }^{5}$ This authoritative advice is mandatory for neurologists, neurosurgeons, neuropathologists, and pathologists, all of whom may handle brain tissue from these patients. Psychiatrists may have patients with Creutzfeldt-Jakob disease in their wards and they should also be aware of this report.

Anxieties about the possibility of infection by patients with Creutzfeldt-Jakob disease are entirely rational, but there is no evidence to suggest that they are infectious under general nursing care when proper precautions are taken. These include the use of gloves and disposable gowns in routine nursing procedures such as handling bloodstained dressings or cleaning bed sores. Laboratory specimens should be handled with the special precautions laid out in the code of practice for the prevention of infection in clinical laboratories and postmortem rooms. The recommendations for dealing with patients with Creutzfeldt-Jakob disease suggested by the advisory group are timely and their conclusions will serve to allay present anxieties.

P O BEHAN

Consultant Neurologist and Reader in Neurology,

Institute of Neurological Sciences,

Southern General Hospital,

Glasgow G51 4TF

1 Will RG, Matthews WB. Evidence for case-to-case transmission of Creutzfeldt-Jakob disease. F Neurol Neurosurg Psychiatry 1982;45:235-8.

2 Gajdusek DC, Gibbs CJ Jr, Asher DM, et al. Precautions in medical care of, and handling materials from, patients with transmissible virus dementia (Creutzfeldt-Jakob disease). N Engl f Med 1977;297:1253-8.

3 Brown P, Cathala F, Gajdusek DC. La maladie de Creutzfeldt et Jakob. Précautions pour les gestes diagnostiques, et thérapeutiques: les nécropsies. Rev Neurol (Paris) 1978;134:277-86.

${ }^{4}$ Matthews WB. Spongiform virus encephalopathy. In: Matthews WB, Glaser GH, eds. Recent advances in clinical neurology. 3. Edinburgh: Churchill Livingstone, $1982: 229-38$.

${ }^{5}$ Advisory Group on the Management of Patients with Spongiform Encephalopathy (Creutzfeldt-Jakob Disease (CJD)). Report of the Chief Medical Officers of the Department of Health and Social Security, the Scottish Home and Health Department and the Welsh Office. London: HMSO, $1981: 1-5$.

\section{Social work: effective or affective?}

In 1980 the Secretary of State for Social Services invited the National Institute for Social Work to make an inquiry into the "role and tasks" of social workers. The report of the working party, chaired by $\mathrm{Mr} \mathrm{P} M$ Barclay, has recently been published. ${ }^{1}$ Its main recommendation is a move to community social work. This speculative idea has already been criticised by Professor Pinker in a lucid minority report. "The concept of community," he argues, "can never be sufficiently well defined to serve as a framework for formal and equitable social policies ..." Evidently there was also a lack of consensus on many other issues. Not surprisingly, then, the document has been received without acclamation in social work circles. ${ }^{2} 3$

Few of the recommendations have a direct bearing on medical practice. Inevitably the multidisciplinary team is mentioned, with the authors alleging that (outside of the psychiatric sphere) the working relation between social workers and doctors is rarely one of equal partners. One barrier is the doubts in some doctors' minds about the ethical accountability of social workers. These doubts may be reinforced by the report's rejection of proposals for a general council of social work, analogous to the General Medical Council.

At the heart of the report-and its reception by doctorsare the familiar questions: what do social workers do? And, what sort of social work is of benefit to medical patients?

Statutory duties apart, social workers undertake two overlapping activities, neither of which is exclusive to them. Social care planning is based on efforts to improve present, or prevent future, social problems; it comprises assessment, practical advice and service, and administrative affairs. 